\title{
IDENTIFIKASI KESADARAN MASYARAKAT TERHADAP KONSERVASI DAN REHABILITASI BURUNG
}

\author{
Ardi Muhamad Arsyad \\ Universitas Pendidikan Indonesia (UPI) Bandung \\ E-mail : ardi.voxer27@gmail.com
}

Naskah diterima: 18 April 2017, direvisi: 16 Mei 2017, disetujui: 27 Juni 2017

\begin{abstract}
This study aims to determine public awareness of the conservation and rehabilitation of birds on bird traders in Pasundan Market, Sukabumi. The research method used is descriptive method with qualitative approach. Data collection techniques used observation, interviews, questionnaires, documentation, and field notes. The results found in this study is the level of public awareness of bird conservation and rehabilitation on the bird traders is very important to maintain the sustainability of birds that exist in their natural habitat. But in reality there are still many bird traders who sell protected birds obtained from consumers who entrust directly to the traders for resale. The occurrence of such phenomena is due to less supervision by the government. The lack of public awareness of bird conservation and rehabilitation is largely due to the lack of awareness of traders on the understanding of conservation and rehabilitation rules, and the lack of supervision to traders by the government. In addition, the role of the general public to assist oversight also needs to be improved to assist government oversight.
\end{abstract}

Keywords: awareness, conservation, rehabilitation, geography

\begin{abstract}
Abstrak
Penelitian ini bertujuan untuk mengetahui kesadaran masyarakat terhadap konservasi dan rehabilitasi burung pada pedagang burung di Pasar Pasundan, Sukabumi. Metode penelitian yang digunakan adalah metode deskriptif dengan pendekatan kualitatif. Teknik pengumpulan data menggunakan observasi, wawancara, kuisioner, dokumentasi, dan catatan lapangan. Hasil yang ditemukan dalam penelitian ini adalah tingkat kesadaran masyarakat terhadap konservasi dan rehabilitasi burung pada para pedagang burung sangat penting untuk menjaga kelestarian burung yang ada di habitat aslinya. Namun pada kenyataannya masih banyak pedagang burung yang menjual burung yang dilindungi yang didapatkan dari para konsumen yang menitipkan langsung kepada para pedagang untuk dijual kembali. Terjadinya fenomena tersebut disebabkan karena pengawasan yang kurang oleh pemerintah. Kurangnya tingkat kesadaran masyarakat terhadap konservasi dan rehabilitasi burung sangat disebabkan karena kurangnya kesadaran para pedagang terhadap pemahaman peraturan konservasi dan rehabilitasi, serta kurangnya pengawasan kepada para pedagang yang dilakukan oleh pemerintah. Selain itu, peran masyarakat umum untuk membantu pengawasan juga perlu ditingkatkan untuk membantu pengawasan yang dilakukan oleh pemerintah.
\end{abstract}

Kata Kunci: kesadaran, konservasi, rehabilitasi, geografi

Pengutipan: Arsyad, Ardi Muhamad. (2017). Identifikasi Kesadaran Masyarakat terhadap Konservasi dan Rehabilitasi Burung. SOSIO DIDAKTIKA: Social Science Education Journal, 4(1), 2017, 81-91. doi:10.15408/sd.v4i1.4393.

Permalink/DOI: http://dx.doi.org/10.15408/sd.v4i1.4393 


\section{A. Pendahuluan}

Keanekaragaman hayati Indonesia sangatlah banyak dan begitu beragam, hal ini dikarenakan Indonesia memiliki wilayah yang sangat luas dan memiliki keunikan di setiap daerahnya serta berbeda keadaan lingkungannya satu sama lain. Namun keanekaragaman hayati tersebut terancam dengan rusaknya lingkungan alam yang disebabkan karena banyaknya penebangan liar (illegal loging) oleh masyarakat dan sektor swasta lainnya sehingga menyebabkan habitat asli hewan tersebut menjadi rusak dan terganggu kelangsungan hidupnya, bahkan hewan pun diburu oleh masyarakat untuk dimakan, dijual, maupun sebagai tambahan koleksi hewan langka.

Maraknya perdagangan ilegal yang memperjualkan hewan langka menjadi faktor yang berkembang dalam pemikiran masyarakat terutama karena nilai jual hewan langka tersebut sangat tinggi dipasaran. Hal ini diperkuat dengan pendapat dari Elizabeth L. Bennet dan Sharon Guynup :

We've devoted one-third of this volume to bunting and the wildlife trade, a conservation threat that ecompasses a complex range of issues and continues to grow in tandem with burgeoning human population and growing international markets. Throughout our history, humans have haunted, collected, and fished wild species for food, clothing, decoration, and medicines. But the scale on which we do so has escalated so rapidly in recent years that human exploitation is arguably the greatest threat to wildlife worldwide. Round the globe, wild animals are being threatened by voracious and unsustainable harvesting. ${ }^{1}$

Dari pendapat di atas dapat disimpulkan bahwa faktor utama yang menyebabkan hewan langka adalah manusia yang memburu hewan dan digunakan sebagai bahan makanan, sebagai dekorasi bahkan digunakan sebagai obat. Penyebab yang lain dari kelangkaan hewan adalah perdagangan hewan dengan tujuan komersial. Dengan banyaknya ancaman terhadap kelangsungan hewan tersebut, maka sangatlah penting untuk menjaga kelestarian hewan dan sebuah konservasi yang menjadi jawabannya. Menurut Rombang dan Rudyanto "bahwa dalam bahasa resmi di Indonesia ada dua kata untuk menerangkan kegiatan yang berhubungan dengan konservasi, yaitu pelestarian dan perlindungan. Dengan pertimbangan alasan praktis,

1 Sharon Guynup, State of The Wild: A Global Portrait Of Wildfe, Wildlands, And Oceans, (Washington, D.C: Island Press, 2006), h. 95. kata konservasi digunakan untuk mengganti kedua kata tersebut". ${ }^{2}$ Dalam konservasi tersendiri kegiatan pelestarian dan perlindungan sudah termasuk tujuan konservasi, menurut Indrawan, Primack, Supriatna "tujuan konservasi mengembangkan pendekatan praktis untuk mencegah kepunahan spesies, menjaga variasi genetik dalam spesies, serta melindungi dan memperbaiki komunitas biologi dan fungsi ekosistem terkait". 3

Seluruh kawasan koservasi di Indonesia berada di bawah pengelolaan Departemen Kehutanan. Kawasan konservasi yang dimaksud adalah kawasan suaka alam (yang terdiri dari cagar alam dan suaka marga satwa), taman buru dan hutan lindung. ${ }^{4}$ Dengan disebarnya lokasi konservasi dapat mempermudah dalam pengelolaan dan kontrol terhadap hewan yang langka. Lalu dengan berbagai macam jenis kawasan konservasi yaitu bertujuan untuk pemanfaatan kawasan konservasi secara berkelanjutan yang digunakan bagi kepentingan penelitian, ilmu pengetahuan, pendidikan, menunjang budidaya, pariwisata, dan rekreasi.

Dengan adanya kawasan konservasi ini dapat melindungi hewan yang benar-benar akan punah dari kegiatan ilegal yang menyalahgunakan hewan untuk komersil semata, hal ini pun didukung dengan arti dasar sebuah konservasi.

Salah satu hewan yang perlu dilindungi adalah berbagai macam jenis burung langka dan hal ini tidak begitu berjalan ketika di lapangan terutama di Pasar Burung Pasundan, Sukabumi yang masih belum memiliki akan kesadaran untuk bisa bersinergi kepada pihak terkait karena masih adanya pedagang burung yang memperjualkan hewan langka untuk tujuan komersil serta untuk kepuasan konsumen yang memang sangat tertarik dengan hal tersebut.

Letak Pasar Burung Pasundan yang sangat strategis untuk dijadikan sebagai pusat perdagangan burung karena terletak di pusat Kota Sukabumi, yang berdekatan dengan pasar tradisional yang biasa menjadi tujuan utama masyarakat sekitar untuk melakukan kegiatan ekonomi seperti berbelanja dan menjadikan akses yang mudah bagi para distributor/ pemburu hewan untuk menjual hasil tangkapan

2 William M. Rombang \& Rudyanto, Daerah Penting Bagi Burung Jawa \& Bali, (Jakarta, Bogor : Departemen Kehutanan dan Perkebunan, Birdlife International Indonesia Programme, 1999), h. 7.

3 Mochamad Indrawan, Richard B. Primack, Jatna Supriatna, "Biologi Konservasi", dalam Wilson (ed), Biologi Konservasi, (Jakarta: Yayasan Obor Indonesia,2007), h. 3.

4 Rombang, Loc.cit. 
mereka. Oleh karena itu tujuan penelitian ini untuk mengetahui kesadaran masyarakat terhadap konservasi dan rehabilitasi burung di Pasar Burung Pasundan Sukabumi.

\section{B. Pengertian Kesadaran}

Manusia akan sadar terhadap apa yang dilakukan dan akan mengingat apa yang sudah dikerjakan sebelumnya.Secara bahasa kata "kesadaran" mempunyai kata dasar "sadar", yang berawalan kean. Sadar berarti insyaf, paham, mengerti kesadaran berarti mengetahui serta memahami sesuatu hal yang baik secara konkrit maupun abstrak. Untuk memperkuat definisi tentang kesadaran maka perlu dilihat tentang definisi secara keseluruhan, adapun kesadaran dalam bentuk lain adalah pemahaman atau pengetahuan seseorang tentang dirinya dan keberadaan dirinya. Kesadaran merupakan unsur dalam manusia dalam memahami realitas dan bagaimana cara bertindak atau menyikapi terhadap realitas. ${ }^{6}$

Dengan kata lain kesadaran bisa dirasakan oleh manusia dalam segala kegiatan yang dilakukannya dan sadar dengan apa yang sedang manusia lakukan dalam kegiatannya. Kesadaran dapat juga diartikan sebagai semua ide, perasaan, pendapat, dan lain sebagainya yang dimiliki seseorang atau sekelompok orang. Adapun menurut Simorangkir kesadaran adalah sebagai berikut :

Menyadari kemungkinan-kemungkinan untuk mengembangkan kebebasan batin, maka kita dapat membuka diri untuk kebahagiaan, kesehatan dan kepuasan yang senantiasa mengelilinginya. Bila mengenal diri secara lebih mendalam, maka kita akan memperoleh pengertian yang lebih mendalam dan lebih luas pula, serta perasaan aman dan sejahtera. Kita menjadi sehat jasmaniah dan rohaniah, pekerjaan, keluarga dan handai-tolan akan memperoleh arti yang lebih besar dimata kita. ${ }^{7}$

Hal di atas diperkuat dengan pendapat Noor, "kesadaran berarti keadaan tahu, mengerti dan merasa akan yang dilakukan." ${ }^{8}$ Kesadaran juga bisa

5 Tim Penyusun Kamus Pusat Pembinaan dan Pengembangan Bahasa, Kamus Besar Bahasa Indonesia, (Jakarta: Balai Pustaka, 1988), h. 765.

6 Pengertian kesadaran, repository.usu.ac.id/ bitstream /123456789/ 26081/4/ Chapter\%20II. Pdf diakses pada 31/08/2014 pukul 10.31

7 O.P. Simorangkir, Kesadaran, Pikiran Dan Tanggung Jawab, (Jakarta: Yagrat, 1987), h.1.

8 Ahmad Mansur Noor, Peran Moral Dalam Membina Kesadaran Hukum, (Jakarta: Proyek Pembinaan Kemahasiswaan Direktorat Jendral Pembinaan Kelembagaan Agama Islam Departemen Agama RI, 1985), h.17. diartikan sebagai kondisi dimana seorang individu memiliki kendali penuh terhadap stimulus internal maupun stimulus eksternal. Namun, kesadaran juga mencakup dalam persepsi dan pemikiran yang secara samar-samar disadari oleh individu sehingga akhirnya perhatiannya terpusat. Menurut Jung teori kesadaran dibagi menjadi tiga bagian, yaitu : a) Ego merupakan jiwa sadar yang terdiri dari persepsi, ingatan, pikiran dan perasaan-perasaan sadar, b) Personal Unconscious merupakan struktur psyche ini merupakan wilayah yang berdekatan dengan ego. Terdiri dari pengalaman-pengalaman yang pernah disadari tetapi dilupakan dan diabaikan dengan cara repression atau suppression, c) Collective Unconscious merupakan gudang bekas ingatan yang diwariskan dari masa lampau leluhur seseorang yang tidak hanya meliputi sejarah ras manusia sebagai sebuah spesies tersendiri tetapi juga leluhur pramanusiawi atau nenek moyang binatangnya. ${ }^{9}$

Jung tidak berbicara tentang kepribadian melainkan psikhe. Adapun yang dimaksud dengan psikhe ialah totalitas segala peristiwa psikhis baik yang disadari maupun yang tidak disadari. ${ }^{10}$ Namun, dalam kehidupan sehari-hari berbagai kejadian berkelanjutan berada disekitar masyarakat menjadikan sebuah kebiasaan untuk dilakukan oleh masyarakat dapat menyebabkan sebuah fakta sosial dan menentukan ukuran untuk segala sesuatu yang dilakukan oleh masyarakat secara sadar untuk dikerjakannya. Hal ini diperkuat oleh pendapat Edmund Husserl "apa yang mereka lakukan sebagai perwujudan kesadaran mereka dinilai oleh sesuatu yang berada diluar diri mereka (fakta sosial) seperti masyarakat dengan hukum-hukum, norma-norma, atau nilai-nilai yang dipegangnya" ${ }^{11}$

Dengan penjelasan tersebut maka kesadaran tidak dilihat dari sisi psikologi saja tetapi dapat dilihat dari sisi sosialnya dengan dipengaruhi oleh faktor luar seperti fakta sosial dan tidak dipengaruhi dari faktor internal manusianya saja yaitu individu manusia itu tersendiri. Adapun menurut Durkheim pengertian kesadaran dari sisi sosialnya adalah sebagai berikut :

Gejala-gejala sosial masyarakat tidak dapat

9 Pengertian kesadaran dan tingkatannya, eedha-dhori.blogspot.com/2011/11/kesadaran-dan-tingkatannya.html diakses tanggal 31/08/2014 pukul 10.37

10 Agus Sujanto, Halem Lubis, dan Taufik Hadi, Psikologi Kepribadian, (Jakarta : Bumi Aksara, 1993) cet. Keenam, h.67.

11 Bernard Raho, Teori Sosiologi Modern, (Jakarta: Prestasi Pustaka, 2007), h.128. 
diterangkan oleh psikologi, tetapi hanya oleh sosiologi. Sebab yang mendasari gejala-gejala sosial itu adalah suatu "kesadaran kolektif" dan bukan "kesdaran individual", sehingga gejalagejala sosial yang menurut Durkheim didasari oleh jiwa kolektif, hanya dapat dipelajari oleh sosiologi yang mempelajari jiwa kolektif itu, dan tidak oleh psikologi yang menurut Durkheim hanya mempelajari gejala-gejala individual. ${ }^{12}$

Dengan begitu kesadaran kolektif terbentuk akibat gejala-gejala sosial yang ditimbulkan masyarakat akibat memiliki pemikiran yang sama dilingkungan masyarakat tersebut dan akhirnya menimbulkan sebuah gejala-gejala sosial. Hal tersebut didukung dengan pendapat Durkheim "masyarakat itu terdiri atas kelompok-kelompok manusia yang hidup secara kolektif dengan pengertian-pengertian kolektif dan tanggapantanggapan secara kolektif". ${ }^{13}$

Secara umum masyarakat pastilah akan mempengaruhi satu sama lain untuk melakukan sebuah tindakan maka dengan pengaruh tersebut dapat terbentuknya sebuah kelompok yang memiliki pemahaman yang sama dan melakukan sebuah tindakan yang sama pula untuk mencapai tujuan yang disepakati bersama dan menyebabkan sebuah perilaku kolektif. Adapun pengertian perilaku kolektif adalah pengalihan kontrol yang sederhana (dan rasional) terhadap tindakan satu pelaku kepada pelaku lain. ${ }^{14}$

Hal tersebut sejalan dengan apa yang dimaksud dengan perilaku kolektif oleh Hanurawan "perilaku kolektif adalah cara berfikir, berperasaan dan bertindak sekumpulan individu yang secara relatif bersifat spontan dan tidak terstuktur yang berkembang dalam suatu kelompok atau suatu populasi sebagai akibat dari saling stimulasi antar individu. $" 15$

Perilaku kolektif tersebut terbentuk dari individu yang mempengaruhi individu lain sehingga membuat sebuah komunitas. Secara umum perilaku kolektif memiliki beberapa elemen yaitu : (a) fenomena tersebut melibatkan sejumlah orang

12 Gerungan, Psikologi Sosial, (Bandung : PT. Eresco, 1988), h. 35-36.

13 Gerungan, Psikologi Sosial, (Bandung : PT. Eresco, 1988), h. 36.

14 James S. Coleman, Dasar-Dasar Teori Sosial, (Bandung: Nusa Media, 2011), h.271.

15 Fattah Hanurawan, Psikologi Sosial Suatu Pengantar, (Bandung : PT. Remaja Rosdakarya, 2010), h. 99. yang melakukan tindakan yang sama pada waktu yang bersamaan; (b) Perilaku yang ditampilkan tersebut bersifat sementara atau terus menerus berubah, tidak dalam kondisi seimbang/stabil; (c) Terdapat semacam ketergantungan tertentu diantara tindakan-tindakan tersebut; individu tidak bertindak secara bebas. ${ }^{16}$

Elemen-elemen tersebut akan menimbulkan apa yang dimaksud dengan perilaku kolektif dan perwujudan dari perilaku kolektif yaitu dengan adanya bentuk-bentuk perilaku kolektif yang digolongkan untuk melihat bagian-bagian dari perilaku kolektif itu sendiri.

\section{Kegiatan Perdagangan Burung}

Awal mula kegiatan perdagangan sudah terjadi sejak zaman dahulu yaitu dengan melakukan kegiatan barter (saling tukang menukar barang yang diinginkan). MenurutSukirno "Dalam perekonomian subsistem yang masih sangat primitif, perdagangan dilakukan secara barter, yaitu perdagangan secara pertukaran barang dengan barang". ${ }^{17}$ Perdagangan yang modern saat ini menggunakan alat tukar untuk barang yang disebut dengan uang.

Dalam kegiatan perdagangan bukan hanya barang saja yang menjadi faktor utama tetapi harus ada tujuan untuk mengambil untung serta perhitungan yang jelas dalam pembukuannya agar dapat melihat catatan keuangan yang jelas dan memberikan motivasi untuk melakukan kegiatan perdagangan kepada pedagang. Hal ini sejalan dengan pendapat Sukardi "Orang-orang enterprising (usaha) memilih nilai-nilai, tujuan dan tugas-tugas melalui yang mana ia dapat mengekspresikan keberaniannya dalam mengambil resiko, kebutuhan untuk menguasai orang lain". ${ }^{18}$ Perdagangan yang dilakukan oleh masyarakat tidaklah semuanya memiliki legalitas dalam perdagangannya namun banyak pula para pedagang yang melakukan perdagangan secara ilegal, tanpa perizinan yang sah dari pihak pemerintah. Hal tersebutlah yang sering terjadi dalam perdagangan burung khususnya bagi burung-burung langka yang memang dilindungi oleh Peraturan Pemerintah Republik Indonesia Nomor 7 Tahun 1999 tentang pengawetan jenis tumbuhan dan satwa, adapun isinya adalah sebagai berikut:

16 James S. Coleman, Dasar-Dasar Teori Sosial, (Bandung : Nusa Media, 2011), h.271.

17 Sadono Sukirno, Mikro Ekonomi Teori Pengantar, (Jakarta: PT. RajaGrafindo Persada, 2005), h.33.

18 Dewa Ketut sukardi, Psikologi Pemilihan Karir, Jakarta: PT. Rineka Cipta, 1993), h.34. 
Dikatakan bahwa tumbuhan dan satwa adalah bagian dan sumber daya alam yang tidak tenilai harganya sehingga kelestariannya perlu dijaga melalui upaya pengawetan jenis sebagai pelaksanaan Undang-Undang Nomor 5 Tahun 1990 tentang konservasi sumber daya alam hayati dan ekosistemnya, dipandang perlu untuk menetapkan peraturan tentang pengawetan jenis tumbuhan dan satwa dengan Peraturan Pemerintah. ${ }^{19}$

Dari peraturan di atas sudah jelas bahwa perdagangan burung yang dilindungi adalah kegiatan yang ilegal dan dapat dikenakan hukuman bagi pelanggarnya dan diperkuat oleh pendapat Kelsen yaitu : "peraturan hukum yang diundangkan oleh penguasa yang berwenang di dalam suatu negara modern mempunyai aspek rangkap. Peraturan hukum yang ditujukan kepada seseorang anggota masyarakat yang menunjukan bagaimana ia harus bertingkah laku (the secondary from of the rule). Sekaligus ditujukan pula kepada hakim apabila anggota masyarakat melanggar peraturan hukum tersebut, maka hakim hendaknya memberikan sanksi terhadap anggota masyarakat itu (the primary from the rule). ${ }^{20}$

Seharusnya para pedagang hewan bisa mengerti bahwa perdagangan burung langka yang dilindungi oleh peraturan yang dibuat oleh pemerintah selayaknya harus ditaati untuk kelestarian hewan tersebut dan pemerintah harus tegas teradap peraturan yang telah berlaku di masyarakat dengan menindak langsung para pedagang yang melakukan kegiatan ilegal tersebut, namun perdagangan burung tersebut juga sudah menjadi permasalahan yang sangat serius di dalam hukum internasional karena maraknya perdagangan dan perburuan burung yang melibatkan banyak negara.

Akibat dari perdagangan dan perburuan terhadap burung atau hidupan liar ini menyebabkan banyak jenis-jenisnya di muka bumi terancam kepunahan. Untuk mengatasi masalah ini maka diadakan kontrol internasional dengan perjanjian CITES (Conference on Parties-COP) yang merupakan konvensi internasional perdagangan species guna membatasi perdagangan ekspor dan impor dari berbagai negara. Adapun tiga kriteria yang disebut

19 PP No. 7 Tahun 1999, Tentang Pengawetan Jenis Tumbuhan dan satwa.

20 Saifullah, Hukum Lingkungan (Paradigma Kebujakan Kriminal di Bidang konservasi Keanekaragaman Hayati), (Malang : UIN Malang Press, 2007), h. 80. lampiran CITES (CITES-Apendix) yang berisi daftar flora dan fauna dengan kriteria khusus.

Adapun tujuan CITES sendiri menurut Chairul, dkk adalah "untuk menjamin bahwa hidupan liar berupa flora dan fauna yang diperdagangkan secara internasional tidak dieksploitasi secara tidak berkelanjutan yang pada akhirnya dapat menyebabkan kepunahan atau langkanya sumberdaya tersebut di habitat alam". ${ }^{21}$ Menurut Sprayitno untuk melaksanakan ini Indonesia menerapkan prinsipprinsip pemanfaatan berkelanjutan yang berdasar pada :

1. Prinsip pemanfaatan tidak merusak (non detriment findings), 2. Prinsip kehati-hatian (precautionary principle). ${ }^{22}$

Prinsip-prinsip tersebut selalu mendasari pengembangan kebijakan pengelolaan spesies yang berkelanjutan. Dengan adanya peraturan yang sangat ketat di dunia internasional maka sudah pasti bahwa hewan yang dilindungi sangat dijaga kelestariannya dari perdagangan hewan yang ilegal. Seharusnya para pedagang juga dapat berperan aktif dalam pelestarian hewan dan hal ini sejalan dengan fatwa Majelis Ulama Indonesia No.4 Tahun 2014 tentang pelesarian satwa langka untuk menjaga keseimbangan ekosistem pada poin ketiga tentang rekomendasi terhadap pelaku usaha adalah sebagai berikut : a) Menjalankan praktek usaha yang bermanfaat bagi masyarakat banyak dan menjaga kelestarian lingkungan, khususnya satwa dan habitatnya; b) Menaati seluruh ketentuan perizinan; c) Berkontribusi terhadap upaya pelestarian ekosistem dan lingkungan, pembentukan kelompok peduli satwa langka serta pemulihan populasi dan habitat satwa langka, khususnya di tempat perusahaan beroprasi. ${ }^{23}$

Dengan penjelasan fatwa tersebut hal ini harus disikapi dengan sangat serius oleh pemerintah sendiri kepada para pedagang yang memang masih melakukan perdagangan hewan tersebut, walaupun sudah ada peraturan pemerintah yang sudah berlaku maka hal yang selanjutnya oleh pemerintah adalah

21 Chairul, Imelda, dan desmarita, Prosiding "Judical Workshop" Penegakan Hukum atas Perlindungan satwa liar, (Jakarta: PALMedia Creative pro, 2005), h. 8.

22 Suprayitno, Bahan Ajar Teknik Pengelolaan Konservasi Keanekaragaman Hayati, Departemen Kehutanan Pusat Diklat Kehutanan.

23 Fatwa Majelis Ulama Indonesia No.4 Tahun 2014, Tentang Pelesarian Satwa Langka Untuk. Menjaga Keseimbangan Ekosistem, (Jakarta : Direktorat Jenderal Perlindungan Hutan dan Konservasi Alam, 2014) h.15 
pengawasan dan penyuluhan yang baik kepada para pedagang sehingga mengerti akan pentingnya menjaga kelestarian hewan khususnya burung yang diperjual belikan di daerah Pasar Pasundan Sukabumi.

\section{Konservasi dan Rehabilitasi}

\section{Pengertian Konservasi}

Pada dasarnya latar belakang dari konsevasi dilandasi oleh kesejahteraan hewan (Animal Welfare) yaitu suatu usaha untuk memberikan kondisi lingkungan yang sesuai bagi satwa sehingga berdampak ada peningkatan sistem psikologi dan fisiologi satwa. Menurut Muhammad Nuriy "kegiatan konservasi merupakan kepedulian manusia untuk meningkatkan kualitas hidup bagi satwa yang terkurung dalam kandang atau terikat tanpa bisa leluasa bergerak".

Dengan adanya kesejahteraan hewan tersebut maka hewan tak seharusnya dikurung, diikat, bahkan sampai dibunuh untuk diambil dagingnya maupun bagian tubuh lainnya untuk dimanfaatkan oleh manusia.

Salah satu konsep mengenai animal welfare yang banyak dipakai oleh para penyayang binatang adalah konsep dari World Society for Protection of Animals (WSPA). Konsep animal welfare dari WSPA dikenal dengan nama "Five (5) Freedom". Ketentuan ini mewajibkan semua hewan yang dipelihara atau hidup bebas di alam memiliki hak-hak/kebebasan berikut: (a) Freedom from hunger and thirst (bebas dari rasa lapar dan haus); (b) Freedom from discomfort (bebas dari rasa panas dan tidak nyaman); (c) Freedom from pain, injury, and disease (bebas dari luka, penyakit dan sakit); (d) Freedom from fear and distress (bebas dari rasa takut dan penderitaan); (e) Freedom to express normal behavior (bebas mengekspresikan perilaku normal dan alami). ${ }^{24}$

Kesejahteraan hewan yang bertujuan untuk melindungi hewan untuk tidak dieksploitasi oleh manusia untuk kepuasan yang tidak ada batasnya, dengan adanya prinsip 5 kebebasan hewan tersebut seharusnya hewan dapat diperlakukan lebih layak sebagai sesama makhluk hidup yang tinggal di bumi ini dan hidup layak untuk makan, tumbuh, berkembang biak dalam lingkungan yang sama.

Secara umum konservasi dapat dikatakan sebagai kawasan tempat pengawetan atau perlindungan keanekaragaman hayati yang

24 Abrianto, Kesejabteraan Hewan. http://duniasapi. com/kesejahteraan-hewan. Diakses 10 september pukul 02.16 tersebar di seluruh Indonesia maupun dunia. Hal tersebut didukung dengan Konferensi Tingkat Tinggi mengenai Lingkungan dan Pembangunan yang dilangsungkan di Rio de Janeiro, Brazil pada tahun 1992 merupakan peristiwa penting dalam upaya konservasi keanekaragaman hayati dunia. Dalam konferensi yang dihadiri oleh utusan dan 157 negara ini, disepakati Konferensi Perserikatan Bangsa-Bangsa mengenai keanekaragaman hayati. Konferensi ini merupakan pernyataan negara-negara penandatangan untuk menyepakati prinsip-prinsip yang berkaitan dengan keanekaragaman hayati dunia, yaitu: (a) Keanekaragaman hayati sangat berharga bagi umat manusia saat inidan di masa mendatang; (b) Ancaman terhadap kelestanian keanekaragam hayati akibat proses pemanfaatan dan kegiatan manusia Iainnya semakin meningkat; (c) perlu ada kesamaan pandangan dan kerjasama di antara bangsa-bangsa di dunia dalam mengelola, memanfaatkan, dan melestarikan keanekaragaman hayati. ${ }^{25}$

Menurut Facrul "dari konferensi tersebut (Konferensi Tingkat Tinggi mengenai Lingkungan dan Pembangunan, Rio de Janeiro, Brazil 1992), Indonesia banyak menerbitkan UndangUndang tentang Perlindungan dan Pengawetan Keanekaragaman Hayati, diantaranya UndangUndang No. 5 Tahun 1994 tentang Pengesahan Konvensi Perserikatan Bangsa-Bangsa mengenai Keanekaragaman Hayati”. ${ }^{26}$

Selain melahirkan UU No. 5 Tahun 1994, Saifullah menambahkan dan menyampaikan bahwa :

Undang-Undang No.5 Tahun 1994 pengertian kawasan konservasi dapat diuraikan berdasarkan Pasal 1 jis. Pasal 14 jis. Pasal 29 UndangUndang No.5 tahun 1990 jis. Pasal 7 dan Pasal 30 Peraturan Pemerintah No.68 Tahun 1998 yang menetapkan hutan konservasi meliputi kawasan hutan suaka alam dan kawasan hutan pelestarian alam, sedangkan Pasal 6 ayat (2) huruf a jo. Pasal 7 Undang-Undang No.41 Tahun 1999 menyebutkan hutan konservasi meliputi kawasan hutan suaka alam, kawasan hutan pelestarian alam dan taman buru. ${ }^{27}$

25 William M. Rombang \& Rudyanto, Daerah Penting Bagi Burung Jawa \& Bali. (Jakarta, Bogor : Departemen Kehutanan dan Perkebunan, Birdlife International Indonesia Programme, 1999) h. 16.

26 Melati Ferianita Facrul, Metode Sampling Bioekologi, (Jakarta: PT Bumi Aksara, 2008), h. 167-168.

27 Saifullah, Hukum Lingkungan (Paradigma Kebujakan Kriminal di Bidang konservasi Keanekaragaman Hayati), (Malang : 
Dari peraturan undang-undang tersebut maka di perbaharui lagi guna menyesuiakan dengan keadaan habitat satwa yang dilindungi. Hal tersebut di paparkan oleh Riyadi tentang Lembaga konservasi menurut Peraturan Menteri Kehutanan No. P.53 Tahun 2006 tentang lembaga konservasi adalah lembaga yang bergerak di bidang konservasi tumbuhan dan atau satwa liar di luar habitatnya (exsitu) yang berfungsi untuk pengembangbiakan dan atau penyelamatan tumbuhan dan atau satwa dengan tetap menjaga kemurnian jenis guna menjamin kelestarian keberadaan dan pemanfaatannya. ${ }^{28}$

\section{Pengertian Rehabilitasi}

Rehabilitasi adalah salah satu bagian dari proses konservasi yaitu proses dimana biasanya hewan akan di tangkarkan untuk dirawat dari lingkungan aslinya yang sudah rusak maupun dari sitaan masyarakat yang memeliharanya secara ilegal sehingga setelah proses ini hewan dapat dikembalikan lagi ke lingkungan atau habitat aslinya. Adapun pengertian penangkaran lebih lanjut dalam PP. No.28 Tahun 2011 “adalah upaya perbanyakan melalui pengembangbiakan dan pembesaran benih/ bibit atau anakan dari tumbuhan liar dan satwa liar, baik yang dilakukan di habitatnya maupun di luar habitatnya, dengan tetap memperhatikan dan mempertahankan kemurnian jenis dan genetik". ${ }^{29}$ Sehingga dengan proses penangkaran ini satwa dapat dikembangbiakkan dan dikembalikan ke habitat asalnya, hal ini sejalan dengan pengertian Pusat Rehabilitasi Satwa di Peraturan Menteri Kehutanan Nomor : P.53/Menhut-II/2006 adalah lembaga konservasi yang melakukan kegiatan untuk mengadaptasikan satwa yang karena suatu sebab berada di lingkungan manusia untuk dikembalikan ke habitatnya.

Dengan pernyataan di atas maka dapat disimpulkan bahwa rehabilitasi adalah proses dimana hewan dibiasakan kembali untuk terbiasa hidup normal sebelum dilepaskan di habitat aslinya. Salah satu bentuk rehabilitasi adalah penangkaran hewan yang dilakukan oleh lembaga pecinta lingkungan maupun oleh lembaga yang berada di bawah pemerintahan.

UIN Malang Press, 2007), h. 122.

28 Anggun Riyadi, Taman Satwa Taru Jurug Kota Surakarta, Skripsi, Fakultas Teknik, Universitas Brawijaya, Malang, 2009, h.15.

29 PP No.28 Tahun 2011, http//www.forda-mof.org, diakses pada tanggal 14/07/14 pukul 12.47

\section{E. Metode Penelitian}

Metode penelitian yang digunakan adalah metode deskriptif dengan pendekatan kualitatif. Teknik pengumpulan data menggunakan observasi (pengamatan), wawancara, angket atau kuisioner, dokumentasi dan catatan lapangan. Pemeriksaan dan pengecekan data dalam menguji credibility dan transferability. Penelitian ini menggunakan teknik triangulasi metode, dengan menyesuaikan studi pendalaman observasi, teknik wawancara dan dokumentasi.

\section{F. Hasil Penelitian dan Pembahasan}

Jika membahas tentang apa yang dimaksud dengan kesadaran maka secara umum kebanyakan orang akan teringat dengan kepribadian dirinya tentang sebuah pikiran, dan tentang segala kegiatan yang telah dilakukannya. Menurut Freud, "kesadaran itu merupakan suatu bagian terkecil atau tipis dari keseluruhan pikiran manusia". ${ }^{30}$ Kesadaran berawal dari individu manusia itu tersendiri tetapi bisa berkembang menjadi kesadaran kolrktif jika mempengaruhi lingkungan masyarakatnya dan menghasilkan perilaku kolektif yang terjadi dikelompok masyarakat tersebut. Hal ini sejalan dengan pendapat Smelser, menyatakan bahwa: "collective behavior as the relatively spontaneous and unstuctured behavior of a group of people who are reacting to a common influence in an ambigouous situation". ${ }^{31}$

Dalam kegiatan perdagangan burung di Pasar Pasundan Sukabumi pada dasarnya dilakukan karena ada kebutuhan masyarakat dalam hal untuk memenuhi kebutuhan burung sebagai bahan makanan, sebagai dekorasi, sebagai obat maupun sebagai pemenuhuan untuk hobi memelihara burung semata. Dalam kegiatan perdagangan burung seringkali para pedagang menjadi acuh terhadap konservasi dan rehabilitasinya dengan kata lain tidak peduli dengan populasi burung di alam bebas karena para pedagang hanya berfikir untuk memenuhi kebutuhan ekonomi dan hanya sebagian kecil yang beranggapan bahwa menjaga populasi burung sangat penting.

Pada sebagian masyarakat pedagang burung di pasar burung Pasundan Sukabumi, penjualan burung dilakukan bahkan ketika burung masih 30 http://www.psikologizone.com/teori-sigmundfreud/06511598diaksespada 31 Agustus 2014 pukul 10.44

31 Richard T. Schaefer, Sociology, (United States : McGraw-Hill, 2008), h.524. 
dalam sarangnya dan burung tersebut masih berwarna merah biasa dicari masyarakat (pembeli) untuk dipelihara dari kecil sebagai burung koleksi.

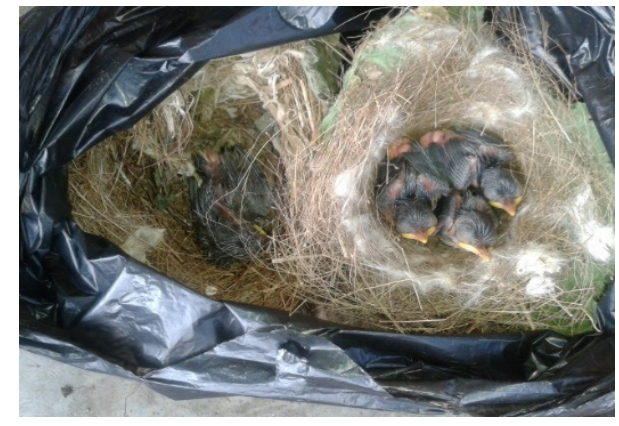

Gambar 1. Anakan Burung Ciplek

Hasil Observasi dan Wawancara terkait pertanyaan penting tidaknya konservasi dan rehabilitasi pada burung, didapatkan bahwa masyarakat Pasar Burung Pasundan Sukabumi menjawab dengan jawaban yang bervariasi, sebagian besar menjawab pentingnya konservasi dan rehabilitasi dan sebagian yang lain menjawab tidak penting. Keberagaman jawaban ini mengidentifikasikan bahwa masyarakat yang menjawab pentingnya konservasi dan rehabilitasi burung telah mengetahui arti penting konservasi dan rehabilitasi burung yang kemudian menunjukkan kesadaran terhadap konservasi dan rehabilitasi burung. Namun, sebagian masyarakat juga menjawab tidak penting adalanya konservasi dan rehabilitasi burung yang menunjukkan bahwa pada masyarakat ini belum memahami arti penting konservasi dan rehabilitasi yang kemudian menunjukkan kurangnya kesadaran terhadap konservasi dan rehabilitasi burung.

Hasil observasi dan wawancara juga menunjukkan bahwa fenomena sosial yang terjadi dimasyarakat pedagang burung yaitu bahwa pada wilayah Pasar Burung Pasundan para pedagang mengetahui tentang peraturan perlindungan burung tetapi ketika ditanyakan lebih rincinya tentang peraturan tersebut sebagian kecil (6 orang) mengetahuinya. Para pedagang yang tahu akan isi peraturan perlindungan burung tersebut mengetahuinya dari berbagai sumber mulai dari televisi, seminar dari pecinta burung, dan dari buku yang biasa dibacanya disisi lain. Sebagian besar (10 orang) tidak tahu tentang isi dari peraturan dan para pedagang merasa tidak tahu karena belum adanya sosialisasi dari pihak pemerintah.

Kesadaran masyarakat terhadap konservasi dan rehabilitasi burung terutama para pedagang burung di Pasar Pasundan Sukabumi semestinya diawali dengan memahami makna dan isi dari peraturan terkait konservasi dan rehabilitasi keanekaragaman hayati. Pemahaman terkait konservasi dan rehabilitasi ini akan menjadi bahan acuan dalam berdagang burung karena tidak semua jenis burung dapat diperjualbelikan dengan bebas dan dengan memahami makna dan isi dari peraturan tersebut, maka para pedagang akan sadar tentang pentingnya menjaga populasi burung di alam bebas. Para pedagang pun dituntut tidak hanya sekedar mengetahui saja tanpa mengetahuimemahami makna dan isi dari peraturan perlindungan burung tersebut sehingga pedagang tidak berfikir acuh untuk menjaga populasi burung di alam bebas. Fenomena sosial ini adalah hasil dari proses kesadaran kolektif yang menimbulkan perilaku kolektif dengan mengembangkan pola pikir para pedagang terhadap peraturan tersebut namun pada kenyataannya para pedagang mengacuhkan peraturan tersebut sehingga saling mempengaruhi lingkungan sekitar dan secara berkelompok melakukan pelanggaran peraturan tersebut sehingga menjadi sebuah perilaku yang wajar dipandangan para pedagang burung dan dapat disimpulkan bahwa kesadaran dan perilaku kolektif di pasar burung pasundan ini adalah hasil dari pendapat atau opini para pedagang terhadap peraturan konservasi dan rehabilitasi burung tersebut yang akhirnya membentuk suatu sikap yang dihasilkan oleh para pedagang burung sehingga dalam perilaku kolektif hal tersebut tergolong dalam bentuk publik dan opini publik.

Para pedagang pun berharap agar pemerintah bisa mensosialisasikan tentang peraturan perlindungan burung ini agar para pedagang paham tentang peraturan perlindungan burung ini. Selain itu juga para pedagang berpendapat bahwa pengawasan terhadap perdagangan burung yang dilakukan oleh pemerintah di wilayah Pasar Pansundan ini sangat kurang karena pengawasan dilakukan tidak sepenuhnya dan tidak dilakukan pengawasannya secara rutin, hal tersebut sejalan dengan pendapat Dedi Jaenudin pedagang di wilayah Pasar Pasundan "untuk pengawasan dari pemerintah hanya dilakukan awalnya saja ketika ada sidak terhadap para pedagang". ${ }^{32}$ Hal tersebut dibenarkon oleh staf PERHUTANI Chendra Eka Permana "bahwa pengawasan langsung dilapangan tidak berjalan dengan baik karena berbagai kendala yang dialami

32 Hasil wawancara dengan Dedi Jaenudin pada tanggal 9 Agustus 2014 
oleh Badan Konservasi Sumberdaya Alam sebagai penanggung jawab pengawasan tersebut namun yang menjadi kendala utama dilapangan adalah kurangnnya sumber daya manusianya". 33

Pengawasan terhadap para pedagang adalah hal yang sangat penting karena dengan dilakukan pengawasan para pedagang selalu merasa diawasi sehingga perdagang burung yang dilindungi bisa tercegah dan pelaksanaan peraturan perlindungan burung pun dapat dilaksanakan dan menyadarkan para pedagang untuk memahami tentang pentingnya konservasi dan rehabilitasi namun, pada kenyataannya selain pemerintah yang ikut andil dalam kelestarian hewan seringkali perkumpulan pecinta burung bahkan Pusat Penyelamatan Satwa pun turun langsung ke lapangan untuk memberikan pemahaman tentang konservasi dan rehabilitasi burung dan tak jarang pula Pusat Penyelamatan Satwa meminta kepada pedagang ketika pedagang menjual burung yang dilindungi untuk di rehabilitasi. Hal ini searah dengan apa yang dikatakan oleh Edi "Para pedagang diberikan penyuluhan lanngsung dan terkadang menyita bila ada burung yang dilindungi diperjualbelikan". ${ }^{34}$ Hal tersebut sejalan dengan apa yang dikatakan Chendra Eka Permana "untuk meminimalisir kekurangan sumber daya manusia di Badan Konservasi Sumber Daya Alam yaitu dengan bekerja sama dengan Pusat Penyelamatan Satwa Cikananga yang wilayahnya berdekatan dengan lokasi pasar pasundan". 35

Peran serta pihak lain sangat diperlukan untuk mencegah perdagangan di Pasar Pasundan karena dengan cara tersebut bisa mencegah perdagangan burung yang dilindungi disini tidak hanya pemerintah saja yang berperan tetapi perlunya pihak lain dalam melaksanakan peraturan perlindungan burung untuk menimbulkan kesadaran kepada para pedagang. Tetapi masih ada pedagang yang menjajakan burung yang dilindungi kebanyakan beralasan karena kebutuhan ekonomi yang biasa didapatkan dari para pengepul bahkan para konsumen sendiri yang menitipkan burung yang dilindungi untuk dijual, hal ini searah dengan apa yang dikatakan Erwin "Burung dilindungi yang dijual di kios saya adalah titipan konsumen yang meminta untuk dijualkan, dan sebenarnya menjual burung dilindungi cukup

33 Hasil wawancara dengan Chendra Eka Permana pada tanggal 24 November 2014

34 Hasil wawancara dengan Edi pada tanggal 9 Agustus 2014

35 Hasil wawancara dengan Chendra Eka Permana pada tanggal 24 November 2014 lama juga untuk dijualnya". ${ }^{36}$

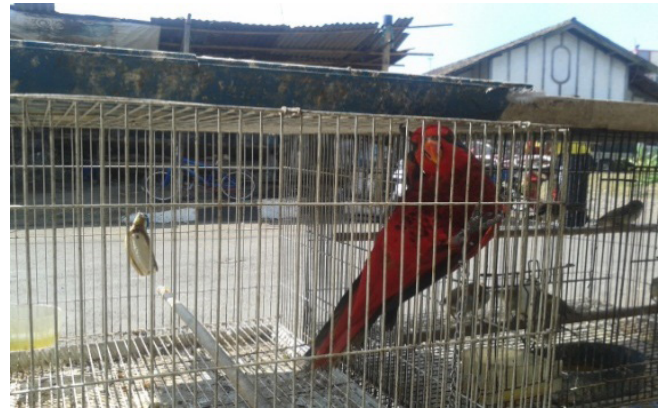

Gambar 2 Burung Nuri (Titipan Konsumen)

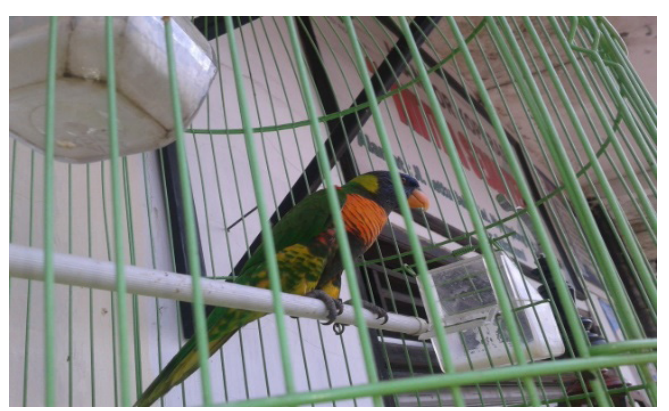

Gambar 3 Burung Nuri Kepala Hitam (Titipan Konsumen)

Dengan sulitnya para pedagang untuk mencari burung yang dilindungi maka terjadilah fenomena baru yaitu para konsumen yang menitipkan burung yang dilindungi untuk dijual yang di dapatkan dari berbagai daerah di Indonesia, hal ini disebabkan juga karena banyak masyarakat daerah lain yang datang ke Sukabumi biasa membawa burung yang dilindungi sebagai oleh-oleh dari daerahnya. Hal tersebut sependapat dengan yang dikatakan Indra Gunawan "Burung yang dilindungi didapatkan dari konsumen yang biasanya di dapat dari para konsumen sendiri dari berbagai daerah lain di Indonesia". 37

Para pedagang pada dasarnya sangat mendukung dengan adanya peraturan perlindungan burung namun, bila ada kejelasan tentang pelaksanaannya maka para pedagang pun akan melaksanakannya dan karena penjelasannya hanya sebatas tahu saja jadi kebanyakan pedagang hanya sebatas tahu saja dan merasa tidak jelas dengan peraturan tersebut. Para pedagang pun berharap agar pemerintah berperan aktif dalam permasalahan ini dan dilakukan secara tegas dan serius agar semuanya menjadi jelas dan tidak membingungkan bagi para pedagang burung di wilayah Pasar Pasundan.

Dilihat dari berbagai keadaan yang terjadi dilapangan seharusnya pemerintah bisa bergerak

36 Hasil wawancara dengan Erwin pada tanggal 9 Agustus 2014

37 Hasil wawancara dengan Indra Gunawan pada tanggal 9 Agustus 2014 
cepat menanggulangi fenomena tersebut agar kelestarian burung bisa terjaga dan secepatnya harus dilakukan penyuluhan terhadap para pedagang sehingga mengetahui informasi mendalam tentang peraturan perlindungan burung sehingga para pedagang serta masyarakat menjadi sadar akan konservasi dan rehabilitasi burung untuk menjaga kelestarian alam serta mengurangi perdagangan burung yang dilindungi.

Adapun langkah-langkah yang dilakukan oleh pihak PERHUTANI dalam pencegahan perusakan kelestarian alam umumnya dan khususnya dalam penyelamatan burung yaitu dengan dibentuknya mandor lapangan yang bertugas di hutan untuk mengawasi hutan serta melakukan pembinaan kepada para masyarakat sekitar hutan dan para petani sekitar hutan yang dinamakan program "Masyarakat Desa Hutan" dan "Kelompok Tani hutan" hal tersebut adalah upaya pencegahan di sektor hulu yang menjadikan sumber langsung dalam pelestarian alam walaupun dalam pelaksanaanya terkendala dari sumber daya manusianya namun, usaha yang dilakukan tersebut adalah sebuah langkah maju yang dilakukan oleh PERHUTANI dalam pelestarian alam.

\section{F. Kesimpulan}

Berdasarkan paparan tersebut diperoleh beberapa kesimpulan. Pertama, identifikasi kesadaran konservasi dan rehabilitasi yang diawali dengan pengetahuan tentang peraturan konservasi dan rehabilitasi burung di Pasar Pasundan, Kota Sukabumi, menunjukkan bahwa para pedagang sebagian besar mengetahui dan sebagian kecil tidak mengetahui tentang peraturan perlindungan burung. Pengawasan terhadap perdagangan di Pasar Pasundan oleh pemerintah tidak berjalan dengan maksimal karena pengawasan hanya dilakukan sesekali saja sehingga para pedagang merasa acuh terhadap peraturan perlindungan burung dan menyebabkan para pedagang masih ada yang menjual burung yang dilindungi. Hal tersebut terjadi karena berbagai kendala yang dialami PERHUTANI dan salah satu yang paling mendasar tentang pengawasan yang tidak berjalan maksimal diakibatkan oleh kurangnya sumber daya manusia dalam pelaksanannya.

Kedua, peran perkumpulan pecinta burung dan Pusat Penyelamatan Satwa dalam penyuluhan dan penyitaan burung yang dilindungi belum cukup efektif dan belum membuat jera para pedagang burung, hanya sebagian pedagang yang mengerti dan paham terhadap peran perkumpulan pecinta burung dan Pusat Penyelamatan Satwa dengan kegiatan yang dilakukannya. Hal tersebut terjadi akibat kurangnya sumber daya manusia dari pihak Badan Konservasi Sumber Daya Alam yang berada dalam satu naungan dengan PERHUTANI.

Ketiga, peran masyarakat umum terhadap pengawasan perdagangan burung dibutuhkan karena mulai adanya fenomena buah tangan jenis burung dilindungi dan membuat konsumen menitipkan burung yang dilindungi berasal dari luar daerah untuk diperjualbelikan.

Keempat, regulasi pemerintah dalam proses penyitaan burung dan proses birokrasi dalam proses penyitaan burung yang kurang jelas karena tidak adanya publikasi kepada para pedagang tentang hewan yang telah disita bahwa benar telah dikembalikan ke habitat asalanya, sehingga para pedagang menjadi kurang percaya kepada pemerintah. Dalam birokrasi para pedagang merasa tidak jelas karena untuk mengurus pemberkasan hasil penyitaan yang tidak tahu harus diurus ke mana dan prosesnya sangat berbelit. Hal tersebut terjadi karena kurangnya sosialisasi yang dilakukan karena keterbatasan sumber daya manusia sehingga para pedagang menjadi tidak mengerti dengan proses yang harus dilaluinya.

\section{G. Daftar Pustaka}

Abrianto, Kesejahteraan Hewan. http://duniasapi. com/kesejahteraan-hewan. Diakses $10 \mathrm{sep}-$ tember pukul 02.16

Agus Sujanto, Halem Lubis, dan Taufik Hadi. 1993. Psikologi Kepribadian. Jakarta : Bumi Aksara. cet. Keenam

Ahmad Mansur Noor. 1985. Peran Moral Dalam Membina Kesadaran Hukum. Jakarta: Proyek Pembinaan Kemahasiswaan Direktorat Jendral Pembinaan Kelembagaan Agama Islam Departemen Agama RI

Anggun Riyadi. 2009. Taman Satwa Taru Jurug Kota Surakarta. Skripsi. Fakultas Teknik. Universitas Brawijaya. Malang.

Bernard Raho. Teori Sosiologi Modern. 2007. Jakarta : Prestasi Pustaka.

Chairul, Imelda dan desmarita. 2005. Prosiding "Tudical Workshop" Penegakan Hukum atas Perlindungan satwa liar. Jakarta: PALMedia Creative pro. 
Dewa Ketut sukardi. 1993. Psikologi Pemilihan Karir. Jakarta: PT. Rineka Cipta.

Facrudin M. Mangunjaya. 2005. Konservasi Alam Dalam islam. Jakarta: Yayasan Obor Indonesia.

Fattah Hanurawan. Psikologi Sosial Suatu Pengantar. 2010. (Bandung : PT. Remaja Rosdakarya.

Fatwa Majelis Ulama Indonesia No.4 Tahun 2014. 2014. Tentang Pelesarian Satwa Langka Untuk Menjaga Keseimbangan Ekosiste. Jakarta : Direktorat Jenderal Perlindungan Hutan dan Konservasi Alam.

Gerungan. Psikologi Sosial. 1988. Bandung : PT. Eresco.

http://mudjiarahardjo.com/materi-kuliah/270.

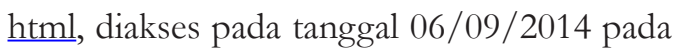
pukul 20.50.

http://www.psikologizone.com/teori-sigmundfreud/06511598 diakses pada 31 Agustus 2014 pukul 10.44

James S. Coleman. Dasar-Dasar Teori Sosial. 2011. Bandung : Nusa Media.

Mochamad Indrawan, Richard B. Primack, Jatna Supriatna. 2007. "Biologi Konservasi”, dalam Wilson (ed), Biologi Konservasi. Jakarta: Yayasan Obor Indonesia.

Muhammad Nuriy Nuha Naufal ,http://diaryveteriner.blogspot.com / 2011/11/ kesejahteraan-hewan-animal-welfare.html diakses 9 september 2014 pukul 15.03
O.P. Simorangkir, 1987. Kesadaran, Pikiran Dan Tanggung Jawab. Jakarta: Yagrat.

Peraturan Menteri Kehutanan Nomor : P.53/Menhut-II/2006. http.www.ditjenphka.dephut. go.id/wp-contentuploads / 201308/Nomor-P.53Menhut-II2006.pdf. diakses pada 19/07/2014 pukul 08:34.

PP No. 7 Tahun 1999. Tentang Pengawetan Jenis Tumbuhan dan satwa.

Richard T. Schaefer. Sociology. 2008. United States : McGraw-Hill.

Sadono Sukirno. 2005. Mikro Ekonomi Teori Pengantar. Jakarta: PT. RajaGrafindo Persada.

Saifullah. 2007. Hukum Lingkungan Paradigma Kebujakan Kriminal di Bidang konservasi Keanekaragaman Hayati). Malang: UIN Malang Press.

Sharon Guynup. 2006. State Of The Wild: A Global Portrait Of Wildfe, Wildlands, And Oceans. Washington D.C: Island Press.

Suprayitno, Ir., Bahan Ajar Teknik Pengelolaan Konservasi Keanekaragaman Hayati, Departemen Kehutanan Pusat Diklat Kehutanan.

Tim Penyusun Kamus Pusat Pembinaan dan Pengembangan Bahasa. 1988. Kamus Besar Bahasa Indonesia. Jakarta: Balai Pustaka.

William M. Rombang \& Rudyanto. 1999. Daerah Penting Bagi Burung Jawa \& Bali. Jakarta, Bogor : Departemen Kehutanan dan Perkebunan, Birdlife International Indonesia Programme. 